\title{
Stem cell-based therapy for ameliorating intrauterine adhesion and endometrium injury
}

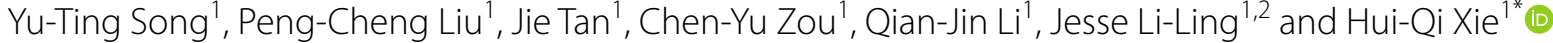

\begin{abstract}
Intrauterine adhesion refers to endometrial repair disorders which are usually caused by uterine injury and may lead to a series of complications such as abnormal menstrual bleeding, recurrent abortion and secondary infertility. At present, therapeutic approaches to intrauterine adhesion are limited due to the lack of effective methods to promote regeneration following severe endometrial injury. Therefore, to develop new methods to prevent endometrial injury and intrauterine adhesion has become an urgent need. For severely damaged endometrium, the loss of stem cells in the endometrium may affect its regeneration. This article aimed to discuss the characteristics of various stem cells and their applications for uterine tissue regeneration.
\end{abstract}

Keywords: Intrauterine adhesion, Endometrium regeneration, Stem cells, Regenerative medicine

\section{Introduction}

In 1948, Joseph Asherman first described the diagnosis, anatomy, etiology, prophylaxis, therapy and complication of a specific type of amenorrhea, which was later referred as Asherman's syndrome (AS) [1], a condition also known as intrauterine adhesion (IUA).

IUA refers to the complication due to damage of endometrial basal layer, for which mechanical trauma, infection and other factors may be attributable. The presence of adhesion tissue may lead to partial or complete obliteration of the uterine cavity and/or cervical canal [2], which may consequently result in deformation or even disappearance of the uterine cavity [3]. Under normal conditions, the endometrial functional layer is periodically shed under hormone regulation, and the basal layers are important for the repair and regeneration of the surface. Therefore, disturbances to the structures of basal layers, such as repair disorder, may exacerbate this process and lead to the occurrence of IUA [3].

\footnotetext{
*Correspondence: xiehuiqi@scu.edu.cn

${ }^{1}$ Laboratory of Stem Cell and Tissue Engineering, Orthopedic Research Institute, Med-X Center for Materials, State Key Laboratory of Biotherapy, West China Hospital, Sichuan University, Chengdu 610041, China Full list of author information is available at the end of the article
}

\section{Formation of adhesion}

IUA may be classified as primary adhesion after pregnancy-related curettage or hysteroscopic surgery, as well as secondary adhesion reoccurred after adhesiolysis [4]. The European Medicine Agency (EMA) has estimated the prevalence of AS to be $0.04 \%$ [5]. More than $90 \%$ of IUA are related to pregnancy [6]. It is usually developed following the manipulation of early abortion or postpartum-related curettage, and may be considered as a postoperative complication of intrauterine surgery $[2,7,8]$. Uterine trauma and postoperative infection, including abdominal myomectomy, cervical biopsy or polylectomy, and insertion of intrauterine device (IUD), are also common causes of IUA [7]. Moreover, reproductive system infection, which may be due to non-pregnancy uterine cavity trauma and congenital uterine malformation, is another risk factor of IUA [9]. Additionally, IUA may also be correlated with irregular uterine dilation, inadequate disinfection, unsoftened cervix, long forceps scraping time or high intraoperative uterine negative pressure.

IUA can cause severe endometrial dysfunctions including infertility and menstrual disorders such as periodic hypogastralgia, hypomenorrhea, amenorrhea, endometriosis, recurrent pregnancy loss, and secondary

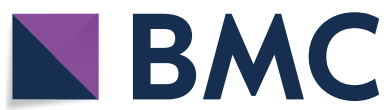

(c) The Author(s) 2021. Open Access This article is licensed under a Creative Commons Attribution 4.0 International License, which permits use, sharing, adaptation, distribution and reproduction in any medium or format, as long as you give appropriate credit to the original author(s) and the source, provide a link to the Creative Commons licence, and indicate if changes were made. The images or other third party material in this article are included in the article's Creative Commons licence, unless indicated otherwise in a credit line to the material. If material is not included in the article's Creative Commons licence and your intended use is not permitted by statutory regulation or exceeds the permitted use, you will need to obtain permission directly from the copyright holder. To view a copy of this licence, visit http://creativecommons.org/licenses/by/4.0/. The Creative Commons Public Domain Dedication waiver (http://creativeco mmons.org/publicdomain/zero/1.0/) applies to the data made available in this article, unless otherwise stated in a credit line to the data. 
infertility [10]. Recurrent miscarriage is associated with IUA too. Approximately $20-30 \%$ of patients with recurrent pregnancy loss suffer from IUA [11-14]. However, it is still uncertain whether IUA is a cause or consequence of recurrent miscarriage [6]. Severe IUA is usually accompanied by endometrial atrophy, which may interfere with embryonic implantation and fetoplacental growth, or even cause infertility [15]. The incidence of IUA among infertile patients is $13 \%$ [7], while $8 \%$ of infertility cases are secondary to IUA [8].

\section{Pathological mechanisms}

The uterus is formed by a mixture of endometrial, muscular and connective tissues. Histologically, the myometrium in IUA resembles that of the normal myometrium, but usually with increased thickness [16]. The connective tissue formed by thin collagen bundles often derives from dense fibrous strips [5]. Endometrial fibrosis is the common pathological manifestation of IUA, where fibrin is the mainly contributor to the formulation of tissue bridges between the walls of uterine cavity [8]. As damaged endometrium cannot be properly repaired, endometrial stromata will be largely replaced by fibrous tissues, glands and inactive cubocolumnar epithelia which is non-responsive to hormonal stimulation [16, 17]. Under such circumstance, the distinction between the functional and basal layers of the endometrium will be lost.

Endometrial trauma may affect the vascularity of endometrium. As illustrated by pelvic angiography, the distribution of vascularity in endometrium and myometrium may be impaired by traumatic endometrial damages [17]. As indicated by previous study, new blood vessels derived from pre-existing vasculature and vasculogenesis plays a pivotal role in the menstrual cycle [18]. However, the newly regenerated fibrotic tissue is usually without vessels and, concomitantly, the paucity of blood supply in IUA patients may also indicate that uterine artery damage is with fibrosis $[7,17]$. Previous studies have shown aberrant activation of fibrosis to be closely associated with pathological changes of IUA [19-22]. Normal wound healing is regulated by a series of complex profibrosis and anti-fibrosis processes [23]. However, excessive endometrial fibrosis may be related to the failure of normal wound healing process, which may aggravate the formation of IUA. Notably, inflammatory response, which occurs following endometrial trauma and may activate down-stream detrimental pathways, is also associated with the process of fibrosis [24].

\section{Classification}

It is necessary to classify IUA in order to summarize their prognosis and correspondingly therapeutic outcome. There are different criteria for the classification of IUA since Asherman original description. Table 1 summarizes the current classification systems and their key features.

In 1978, Toaff and Ballas first classified IUA based on the result of hysterosalpingography (HSG) [25]. They were classified into four grades according to the location and size of the lesion. In the same year, March et al. proposed a hysteroscopic classification of IUA based on the proportion of uterine cavity shown by HSG, which was classified into 3 grades from mild to severe [11]. The method is relatively simple and is still in use today. Nevertheless, based on the extent of the disease, menstrual pattern, and morphological feature of the adhesions, the American Fertility Society had designed a new scoring system in 1988, which could be used in the hysteroscopy and HSG [26], and added menstrual patterns to the rating parameters for the first time. Moreover, they suggested that the location of adhesion may be important for infertile women, so it is necessary to chart the location and extent of adhesions. In the same year, Valle and Sciarra described a new classification based on the extent of uterine cavity occlusion and type of adhesions [27]. Mild adhesions are filmy and composed of endometrial tissue, moderate adhesions are fibromuscular, while severe adhesion or complete occlusion of the uterine cavity are only composed of dense connective tissue, which had the poorest prognosis. Moreover, they concluded that although almost all patients treated with hysteroscopy were able to recover with normal

Table 1 Classification of IUA

\begin{tabular}{|c|c|c|}
\hline Source & Summary of classification & References \\
\hline Toaff and Ballas & Split into four grades according to the lesion location and size & {$[25]$} \\
\hline March et al. & Classified as minimal, moderate, or severe based on the degree of uterine cavity involvement by HSG & {$[11]$} \\
\hline American fertility society & $\begin{array}{l}\text { Complex scoring system of mild, moderate, or severe IUAs based on the extent of cavity obliteration, type of } \\
\text { adhesion, and menstrual pattern according to hysteroscopic or HSG assessment }\end{array}$ & {$[26]$} \\
\hline Valle and Sciarra & $\begin{array}{l}\text { Adhesions classified as mild, moderate, or severe according to the extent of uterine cavity occlusion (partial or } \\
\text { total) and the type of adhesions by HSG }\end{array}$ & {$[27]$} \\
\hline Nasr et al. & Creates a prognostic score by menstrual patterns, reproductive performance and hysteroscopy as parameters & {$[28]$} \\
\hline
\end{tabular}


menstruation, reproductive outcomes parallel the severity of the adhesions.

In 2000, Nasr et al. proposed a new classification method to score IUA using menstrual patterns, reproductive performance and hysteroscopy as parameters [28]. It is the first classification that correlates menstrual pattern and reproductive performance with the prognosis of hysteroscopic adhesiolysis, and they believed that the prognosis depends more upon the type of adhesions and the extent of coverage of tubal ostia. In their proposed rating system, grades I and III were consistent with those of March et al. [11], but for moderate IUAs (grade II), there was an overlap between the two systems (with a sensitivity of $58.3 \%$ ), which may be related to menstrual and reproductive history of patients.

In 2015, the Society of Obstetrics and Gynecology of Chinese Medical Association proposed a new rating scale based on the previous classification. Compared with the previous rating, the table added the previous history of curettage. However, there is still no consensus over the optimum classification of IUA. Further research is needed, particularly for prediction of reproductive prognosis $[6,9]$.

\section{Current treatment options}

Currently, there has been no specific guideline for the treatment of IUA. Various therapeutic approaches have been developed for the repair of endometrial injury and prevention of recurrent adhesions. The most common strategy is transcervical resection of the adhesions (TCRA). Hysteroscopic treatment enables lysis of IUAs under direct vision with magnification, in which only blunt dissection is performed at the tip of the hysteroscope $[29,30]$. Daniel et al. have found that hysteroscopic resection could significantly reduce the incidence of IUA and increase the rate of pregnancy [31].

However, postoperative outcome may vary as the severity of adhesion is diverse and disparate [32]. The more severe the adhesions are, the more difficult dissection and greater risk of the complications will be. According to some studies, the pregnancy rate of patients with mild IUA was close to $95 \%$, while in the severe group the rate was decreased to $60 \%$ after hysteroscopic treatment and subsequent miscarriages percentage could be as high as $75 \%$ [14].

In addition to hysteroscopic treatment, hyaluronic acid gel [33], hormone therapy [34], uterine perfusion [35], and amniotic membrane transplantation [36] have also been used for the treatment of IUA. However, such treatments are only applicable to patients with mild and moderate IUA. Therefore, to develop new methods to prevent endometrial injury and manage IUA has become a major demand.
In 2004, the first evidence for the existence of endometrial stem/progenitor cells in the endometrium was reported [37]. Some researchers hypothesized that endometrial repair disorders may be related to local stem cell damage and loss as regeneration and repairing of the endometrium are closely related with stem cells in the endometrium. Thereby, application of stem cells to treat endometrial injury may be an effective strategy to restore endometrial receptivity. This idea outperforms the conventional treatment and opens a new avenue for the treatment of IUA.

\section{Stem cell therapy}

In 1978, Prianishnikov introduced endometrial stem cells (EnSCs) for the first time [38]. It was not until 2004 that Chan et al. [37] ultimately isolated EnSCs from endometrial tissue, since then the exploration has mounted. Gargett et al. [39, 40] have confirmed the presence of a small number of stromal stem cells and epithelial stem cells in the uterus which could promote endometrial proliferation during the menstrual cycle but were decreased with uterine injury. Such cells were thought to be responsible for the periodic regeneration of the endometrium. Many researchers believe that the homing and migration of stem cells towards the site of lesion plays an important role in tissue regeneration [41-43]. However, there are studies suggesting that the migration and invasion capacities of the stem cells were significantly lower from women with IUA compared with healthy women, which may indirectly affect the self-repairing ability of injured endometrium [44]. Furthermore, when the endometrium is severely damaged, the decrease or loss of stem cells in the endometrium may also affect the regeneration of the endometrium. On the other hand, autologous and allogeneic stem cell transplantation may both be effective for the treatment of IUA [45] (Fig. 1).

With the potential for self-renewal and multi-directional differentiation, stem cells have a broad prospect for the treatment of tissue injury involving the uterine cavity. In recent years, researchers have become focused on the effect of stem cells for the treatment of IUA (Table 2).

\section{Bone marrow stem cells (BMSCs)}

Bone marrow mesenchymal stem cells (BM-MSCs) are easy to culture in vitro, which makes it the most widely used seed cells for stem cell transplantation. BM-MSCs can differentiate into a variety of non-hematopoietic cells including skeletal myoblasts, cardiac myoblasts, skin epithelia, as well as endothelial, renal, hepatic, and lung cells [32]. Compared with endometrial stem cells, BM-MSCs have greater migration ability, which may lead deposition of a higher proportion of donor cells in vitro [46]. Therefore, BM-MSCs has become a promising candidate 


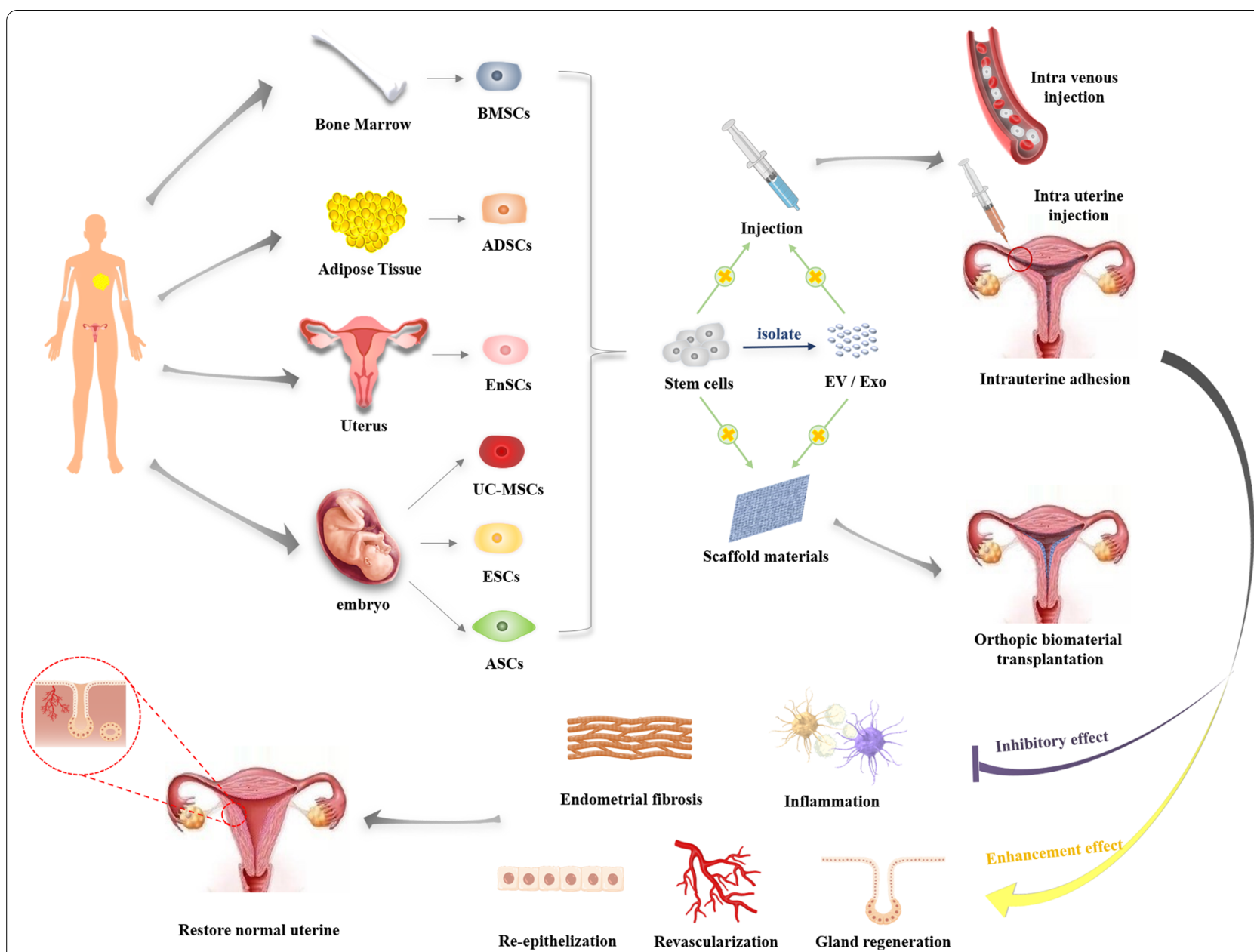

Fig. 1 Stem cell-based approaches to uterus regeneration include (1) intravenous stem cells or EV/ Exo, (2) intrauterine injection stem cells or EV/ Exo and (3) fabrication of synthetic graft by encapsulating stem cell or EV/Exo therapeutics with biomaterials. After transplantation, stem cells can stimulate the angiogenesis, epithelization and gland regeneration while inhibitory inflammation and endometrial fibrosis, and eventually restore normal uterine structure and function

Table 2 Some resources and features of stem cells which contribute in endometrium regeneration

\begin{tabular}{|c|c|c|c|}
\hline Stem cell & Major source & Properties & References \\
\hline BMSCs & Bone marrow & $\begin{array}{l}\text { Multi-potent, highly proliferative, good migration ability, self-renewing, immunomodulatory } \\
\text { properties }\end{array}$ & {$[46,47]$} \\
\hline $\begin{array}{l}\text { Autologous } \\
\text { adult stem } \\
\text { cells }\end{array}$ & Bone marrow & $\begin{array}{l}\text { Donor-derived bone marrow cells have been identified in human uterine endometrium (both stro- } \\
\text { mal and epithelial cells were derived from bone marrow origin). It is unknown whether these cells } \\
\text { originate from bone marrow mesenchymal stem cells or circulating endometrial cells originally } \\
\text { derived from the endometrium and harbored in bone marrow }\end{array}$ & [48] \\
\hline eMSCs & Endometrium & $\begin{array}{l}\text { Multi-potent, highly proliferative, self-renewing; coexpression of CD140b (PDGFR- } \beta \text { ) and CD146, or } \\
\text { expression perivascular markers SUSD2 (W5C5 antibody) SUSD2 }\end{array}$ & [49-51] \\
\hline ESP & Endometrium & $\begin{array}{l}\text { Heterogeneous, presumably containing stem/progenitor cells of each endometrial cell lineage; } \\
\text { produce endometrial endothelial, epithelial, and stromal cells in vitro and in vivo }\end{array}$ & {$[49,52,53]$} \\
\hline UC-MSCS & Umbilical cord & $\begin{array}{l}\text { Derived from the mesoderm in early development; low immunogenicity; multi-potent cells; high } \\
\text { self-renewal ability; multi-differentiation; high proliferative potential }\end{array}$ & {$[54-56]$} \\
\hline ADSCs & Adipose tissue & $\begin{array}{l}\text { Abundant sources; easy sampling; self-renewal; multi-potential differentiation; strong proliferation } \\
\text { ability }\end{array}$ & {$[57-61]$} \\
\hline ESCs & Embryo & $\begin{array}{l}\text { Pluripotent stem cells derived from the inner cell mass of a blastocyst; high telomerase activity; } \\
\text { significant long-term proliferation potential }\end{array}$ & {$[62,63]$} \\
\hline ASCs & Amniotic membrane & Inflammatory suppression, angiogenesis promotion, anti-oxidative stress & {$[64,69]$} \\
\hline
\end{tabular}


seeding cells for repairing uterine damage owing to their merits.

In 2008, Mints et al. [70] have detected presence of $Y$ chromosome in the endometrial cells of a woman who received bone marrow transplants from a male donor. Subsequent studies also illustrated that endometrial angiogenesis was not only from local endothelial cells, but may also come from BMSCs. Cervelló et al. [71] also confirmed the presence of $\mathrm{XY}$ donor-derived bone marrow cells in the endometrium of women receiving male bone marrow transplants, and such cells may be an exogenous source of endometrial trans-differentiation cells.

Although uterine damage was localized, BMSCs could migrate to both sides of the uterus, possibly due to the secretion of particular chemokines [10]. Accordingly, secretion of such signal molecules may be an important mechanism for stem cell therapy for uterine cavity injury. Cervelló et al. [72] found that transplanted CD133(+) BMSC have located around endometrial vessels and could induce proliferation of surrounding cells by regulating paracrine factors such as thrombospondin 1 and insulin-like growth factor 1 . In addition, the expression of leukemic inhibition factor (LIF), an endometrial receptivity marker in the regenerated endometrium, may also in part contribute to the improved reproductive outcome in a rat model for IUA [73].

Studies have suggested that BMSCs transplantation may repair the damaged endometrium by promoting the expression of ER and PR. Wang et al. [74] injected BMSC into IUA rats by uterine and vein, and found that the BMSCs were more abundant in the uterine injection group after 2 weeks. Interestingly, another study comparing the two methods of injection by using green fluorescent protein (GFP)-expressing BMDCs has found that systemic route of administration could result in better recruitment of BMDCs to the injured uterus after 2-3 weeks [46]. Other studies also found that the implantation and conception rates of IUA rats receiving vein injection of BMSCs were comparable to those with normal uteri, while all untreated IUA rats had failed to conceive [73]. Hence, both the systemic route of administration and local injection could rapidly promote formation of new endometrial glands with subsequently replacing fibrotic scars by increasing ER and PR expression [74]. And, strikingly, fluctuations in systemic hormone levels had no effect on the migration of BMSCs [32].

Clinically, BMSCs can improve the reproductive outcome of IUA patients. Nagori et al. [48] discovered that angiogenic stem cells derived from autologous bone marrow derived stem cells could regenerate injured endometrium and lead to successful pregnancy and delivery. In 2011, a woman with severe IUA has received transvaginal injection of autologous bone marrow stem cells, and after a period of time, her endometrial thickness and blood vessel richness gradually increased, allowing her to eventually maintain embryo growth [48]. In 2016, Santamaria et al. [75] used CD133 ${ }^{+}$BMSCs in conjunction with hormonal replacement therapy for IUA. After 2 months of stem cell therapy, endometrial thickness has increased in 11 IUA patients, with simultaneous amplification of endometrial vascular density and duration and intensity of the menstrual cycle in the first 3 months which returned to the original level after 6 months. And three of them eventually conceive naturally.

Some researchers also reported that implantation of combination of BMSCs with scaffold materials into the IUA uterus was feasible. Zhao et al. [76] recellularized a collagen scaffold with high-density BMSCs and implanted them into the uterus of IUA patients, and found that it could reverse endometrial fibrosis and promote endometrial regeneration by down-regulating the expression of Np63. After the treatment, all five patients successfully attained pregnancies and delivered. Collagen/BMSCs system could enhance proliferation of endometrium and muscular cells, facilitate microvasculature regeneration, and restore the function of endometrium to eventually receive the embryos [77]. Recently, it was found that exosomes secreted by BMSCs could transfer miR-340 to endometriotic stromal cells and effectively attenuate endometrial fibrosis [78]. In addition to collagen scaffolds, other polymer scaffolds combined with BMSC were also exploited for endometrial repair. Xiao et al. [79] constructed a BMSC-loaded elastic poly (glycerol sebacate) (PGS) scaffold, within which the BMSCs could be directly differentiated into endometrial stromal cells after transplantation. Moreover, compared with collagen scaffolds, PGS/BMSC also significantly prolonged the retention time of BMSCs in a rat model for uterine injury.

\section{Endometrial stem/progenitor cells (EnSCs)}

Many experiments have confirmed the presence of endometrial stem/progenitor cells, including epithelial stem cells, endometrial mesenchymal stem cells (eMSCs), endothelial progenitor cells (EPCs), which could be activated during the menstrual cycle and conducive to rapid endometrial regeneration following menstruation (Fig. 2). During the past a few decades, the application of EnSCs in uterine regeneration has been rapidly growing for reasons such as high homology with uterine tissue and ease to acquire [80]. Angiogenesis is one of the key steps in endometrial repair. Restructuring and maturation of the vascular network can facilitate embryo implantation [81]. Blood vessel walls are considered as stem cell-niche with a large reservoir of progenitor cells 


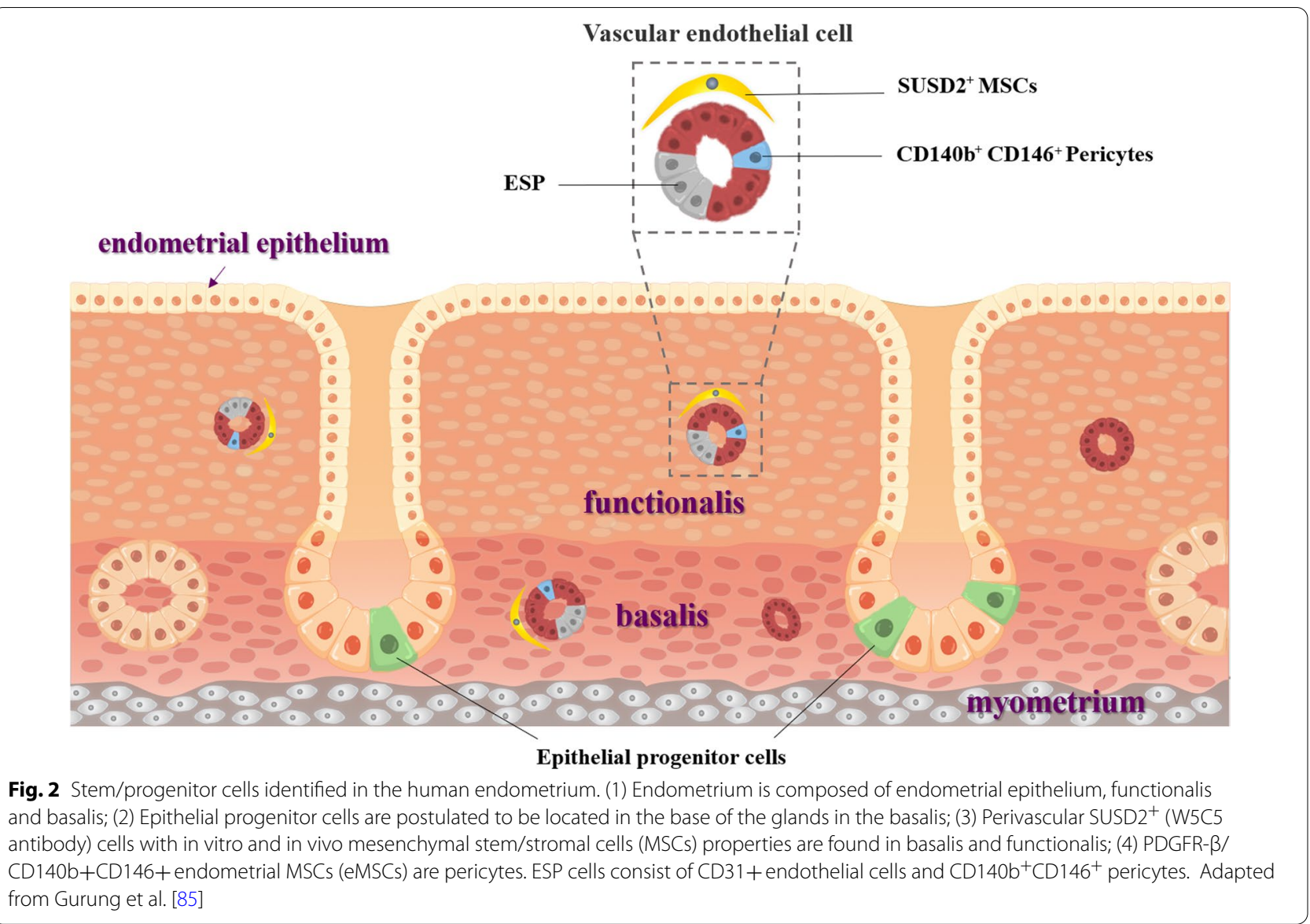

[82]. Previous study has found that eMSCs in the basalis and functionalis are mainly perivascular cells, including $\mathrm{CD}_{146^{+}}$and $\mathrm{CD}_{140 \mathrm{~b}^{+}}$(platelet-derived growth factor- $\beta$, PDGFR- $\beta+)$ pericytes $[50,51]$, sushi domaincontaining $-2^{+}\left(\mathrm{SUSD}^{+}\right)$cells [83] and $\mathrm{CD} 34^{+}$adventitial cells (located in the outermost layer of blood vessels and mainly in the basal layer) [82].

Although both $\mathrm{CD}_{4} 4^{+}$adventitial cells and CD146 ${ }^{+}$ pericytes showed MSCs phenotypes in vitro, they have exhibited a limited potential to regenerate the endometrium. Other studies have shown that $\mathrm{CD} 146^{+} \mathrm{CD} 140 \mathrm{~b}^{+}$ cells could promote endometrial angiogenesis in rats and capillary formation of HUVECs in vitro [44, 84]. eMSCs have also been found to play certain role in regenerating the endometrial stroma in vivo [46].

EPCs are postulated to reside in the glands of the basalis [86], while endometrial endothelial progenitor cells are recognized as side population cells (SP cells) [50]. As one of the potential endometrial stem/progenitor populations, endometrial side population (ESP) was first identified in short-term culture of endometrial cells [53]. ESP cells can generate endometrial endothelial, epithelial, and stromal cells in vitro and in vivo, which are located both in the basalis and functionalis [49]. Cervelló et al. [52] transplanted hESP beneath the renal capsule of NODSCID mice, and found that it could generate human endometrium.

As analogous to other stem cells, EnSCs also have the advantages of self-renewal, multi-differentiation, and high proliferation potential. Such cells can be obtained by scratching the endometrium or isolated from menstrual blood. Such characteristics have made it a potential resource for the treatment of IUA.

Zhang et al. [87] transplanted EnSCs derived from menstrual blood into IUA mice, and found that the endometrial thickness and microvascular density were increased, and the repair of damaged uterus was appreciably accelerated. As reported, EMSCs conditioned medium could activate AKT and ERK pathways, induce overexpression of eNOS, VEGFA, VEGFR1, VEGFR2 and TIE2 in HUVECs, while decrease $\mathrm{H}_{2} \mathrm{O}_{2}$-induced apoptosis of human umbilical vein endothelial cells (HUVECs). In a subsequent study, they found that EnSCs could inhibit myofibroblast activation, resulting in rapid proliferation of epithelial stem cells, which ultimately promoted endometrial wound healing [3]. Moreover, they 
delineated that Hippo/TAZ is the key signal of EnSCs against the process of endometrial interstitial fibrosis [3]. Another group has also found that EnSCs could substantially accelerate the repair of endometrial damage, in which a paracrine effect and activation of Hippo signaling pathway were validated and the effect was found to be even better when combined with the application of platelet-rich plasma (PRP) [88]. Lin et al. [89] reported that Gli2 signaling could also promote endometrial fibrosis by reducing the level of Gli2 protein in EnSCs conditioned medium (EnSCs-CM) and reduce endometrial fibrosis, a process which was critical in blocking the cell cycle of epithelial stem cells through granulocyte-colony stimulating factor (G-CSF).

In 2016, EnSCs have been approved for usage in clinical trials for endometrial regeneration in patients with IUA. Endometrial thickness of all subjects has significantly increased, and some women even became pregnant following frozen embryo transplantation [90]. Furthermore, a clinical trial using autologous menstrual blood-derived stromal cells for treating severe IUA also showed satisfactory results [90].

In recent years, more researches have focused on the paracrine pathway mediated by stem cells. Similar to other MSCs, EnSCs have been reported to mediate IUA repair through paracrine action of extracellular vesicles (EVs) [80]. A recent study has shown that EnSCs-EV have exerted their immunomodulatory function by inhibiting the activation of $\mathrm{CD} 4^{+} \mathrm{T}$ cells [91].

\section{Umbilical cord-derived mesenchymal stromal cells (UC-MSCs)}

Umbilical cord-derived mesenchymal stromal cells (UCMSCs) are multi-potent cells with strong self-renewal ability and multi-differentiation potential. Such cells are derived from the mesoderm in early development and have the advantages of easy collection, low immunogenicity, and high proliferative potential $[54,56]$.

In recent years, some researchers have reported that UC-MSCs could enhance endometrial cell proliferation and vascular remodeling while inhibit excessive fibrosis and inflammation, thereby repair the damaged endometrium and restore fertility [92]. Zheng et al. [93] injected hUC-MSCs into SD rats and showed that it has the ability to differentiate into epithelial cells, vascular endothelial cells, and estrogen receptor cells, which are essential for the supply of blood vessels and interrupting the formation of fibers. All of these could contribute to the restoration of fertility in IUA rats. They also transplanted CM-Dil-labeled hUC-MSCs into rats and found that the hUC-MSCs were not evenly distributed in uterine tissues. More cells had migrated into the stroma and myometrium regions, while almost no cells reached the epithelium of endometrium and gland [93]. They speculated that this may be due to the fact that stroma and myometrium contained more blood vessels than did epithelium, which was in keeping with the fact that MSCs are mainly distributed along the blood vessels [94]. A study has shown that EV could enhance angiogenic processes in endothelial cells [95]. EV derived from hUCMSCs (hUCMSCs-EV) can also be used as a therapeutic agent for IUA, and was more effective when combined with estrogen [96].

Transplanting scaffolds loaded with UC-MSCs has been investigated as well. Xu et al. [97] constructed a collagen scaffold (CS) loaded with UC-MSCs, and noted that this complex could facilitate the degradation of collagen of uterine scar by upregulating MMP-9 secreted by UC-MSCs, which was instrumental for the repair and regeneration of endometrium, myometrium, and blood vessels. Xin et al. [54] also transplanted CS/UC-MSCs into a model for endometrial damage and discovered that it could maintain the normal luminal structure, promote endometrial regeneration and collagen remodeling, and also increase the expression of estrogen receptors and progesterone receptors. Recent studies have shown that transplantation of UC-MSCs and auto-crosslinked hyaluronic acid (HA) gel might have a dual repair effect with an anti-adhesive property and promotion of endometrial regeneration [98]. By implanting this complex to a rhesus monkey model for IUA, they found that UC-MSCs/HAGEL was superior to HA-GEL in repairing IUA caused by mechanical injury.

A phase I clinical trial also confirmed that transplantation of UC-MSCs with biodegradable collagen scaffolds into the uterine cavity (by adhesion separation) in patients with recurrent IUA was effective [99]. Three months after the operation, the average and maximum endometrial thickness had both increased, while the IUA score was decreased. At the end of 30-month follow-up period, 10 of the 26 patients attained pregnancy and 8 of them had delivered without compelling birth defects or placental complications.

\section{Adipose-derived stem cells (ADSCs)}

Adipose-derived stem cells (ADSCs) are also a type of mesenchymal stem cells derived from the mesoderm but mainly exist in adipose tissue. Their typical or specific cell markers include CD90(+), CD73(+), CD105 (+), CD45(-) and CD34(-) [57]. At present, ADSCs are one of the most advantageous and extensively researched adult stem cells for cell therapy and tissue engineering. ADSCs have the advantages of abundant source, easy sampling, capable of self-renewal, multi-potential differentiation, as well as strong proliferation ability, and can be obtained from patients themselves thereby avoid 
ethical problems [59-61]. However, literature on the application of ADSCs for the treatment or prevention of IUA is still scarce. Shao et al. [100] injected green fluorescent protein (GFP)-labelled ADSCs into IUA rats and found that ADSCs could differentiate into endometrial epithelial cells. At 30 days after transplantation, the damaged endometrium was robustly improved, with increased microvascular density, endometrial thickness and glands. The expression of oestrogen and progesterone receptors was also increased. In addition, the fertility of rats was also recovered to some extent. Sun et al. [101] exploited the ADSCs as seed cells to form scaffold-free cell plates with massively retaining of extracellular matrix proteins, growth factors, and a large number of cytokines without enzymolysis [102], and found that ADSCs mainly appeared in the basal layer of the regenerating endometrium at 21 days after transplantation, with some ADSCs differentiated into stromal-like cells.

It has been reported recently that acellular human amniotic membrane (AHAM) can substantially improve the expression of ADSCs angiogenic factors in vitro, and in vivo experiments also demonstrated that hADSCs/AHAM transplantation into damaged uterine cavity could significantly increase vascular density of the rat endometrial tissue [103]. They proposed that the ability of hADSCs/AHAM to repair damaged endometrium may be related to the accelerated angiogenesis, where the expression of angiogenic factors in hADSCs was up-regulated. Zhao et al. [104] have extracted exosomes from ADSCs (ADSC-exo) and applied them to an IUA rat model, and found that ADSC-exo could maintain the normal structure of uterus while improve the endometrial regeneration and reproductivity. They proposed that local application of ADSC-exo in uterus as a novel strategy for the treatment of IUA and infertility. Researchers have recently study have injected autologous ADSCs combined with ShakeGel ${ }^{\mathrm{TM}} 3 \mathrm{D}$ directly into the mice uterus to repair the damaged endometrium and restore the fertility by activating the BMP7-Smad5 signaling pathway [105].

\section{Embryonic stem cells (ESCs)}

Embryonic stem cells (ESCs) are derived from the blastocyst phase of the early mammal embryo. Compared with other stem cells, ESCs are truly pluripotent cells as they have originated from the endoderm of embryo and can differentiate into various cell types in special culture medium $[62,63]$. ESCs have retained a normal karyotype, with high telomerase activity and significant long-term proliferation potential [62]. Such cells have shown promise for the treatment of various diseases including spinal cord injury [106], arrhythmia [107], liver injury [108], diabetes [109], cartilage repair [110], etc. However, so far few have reported application of the ESCs for the treatment of IUA.

In 2015, Yu et al. [111] co-cultured hESCs with mouse endometrial stromal cells to induce differentiation of hESCs into endometrioid epithelium, and their results showed that the expression levels of cytokeratin, epithelial cell adhesion molecule (EpCAM), ER, and PR in the co-culture group were significantly increased on the 21st day after induced differentiation, confirming that hESCs could be differentiated into endometrioid cells [111]. Song et al. [112] also co-cultured hESCs with endometrial stromal cells to induce endometrioid cells, and seeded the hESC-derived cells onto collagen scaffolds and transplanted them into a rat model for severe uterine damage. 12 weeks later, hESC-derived cells were observed to survive and have recovered the structure and function of uterine horn.

Nevertheless, the use of embryo-isolate stem cells has remained to be ethically controversial. Clinical trials have also been debated that in vitro induction of the hESCs can have the risk of tumorigenesis. Therefore, the application of ESCs in the treatment of IUA still has a long way to go.

\section{Amniotic membrane stem cells (AMSCs)}

Amniotic membrane stem cells (ASCs), including amniotic mesenchymal stromal cells (AMSCs) and amniotic epithelial cells (AECs), are stem cell-like cells isolated from the mesenchymal and epithelial layers of the amniotic membrane from discarded amniotic tissue, which are readily available and abundant, with relatively fewer ethical concerns $[64,65]$.

AMSCs possess potential therapeutic features such as inflammatory suppression, angiogenesis promotion, antioxidative stress, and other beneficial properties. They have even shown an immunomodulatory capacity by paracrine action [65-69]. In recent years, AMSCs have been recognized as a suitable alternative source of seed cells for tissue engineering. Gan et al. [113] discovered that transplantation of hAMSCs could lower the level of messenger RNA of pro-inflammatory cytokines while increase that of anti-inflammatory cytokines, which implied that AMSCs can promote endometrial regeneration by immunomodulatory effects.

AECs are embryonic stem cell-like lineages with the capability of differentiation and adult stem cell-like immunomodulatory properties [114]. AECs have shown be effective for the treatment of lung fibrosis [115], brain injury [116], kidney injury [117], and hepatic fibrosis [118]. Recently, researchers have explored therapeutic potential of AECs on IUA. Li et al. [119] found that intraperitoneal injection of hAECs into IUA rats could alleviate fibrogenic progression, increase vascular density and 
restore the structure of uterine cavity. They also found that in vitro co-culturing hAECs with $\mathrm{H} 2 \mathrm{O} 2$-damaged human endometrial mesenchymal stem cells (hEnSCs) could activate autophagy of hEnSCs through paracrine pathways. In 2019, Lai et al. [120] had filed a patent for AECs, which signified that AECs could be used to prevent IUA secondary to endometrium injury, repair the endometrial morphology in a mouse model for IUA, promote endometrial angiogenesis and mesenchymal cell proliferation, and improve the fertility of mice following uterine cavity injury.

\section{Limitation of stem cell therapy}

Stem cell therapy holds a great promise for uterine repair and regeneration. However, despite the remarkable achievements made in the research, their clinical applications still face challenges, as most studies have been conducted on animal models with non-standardized study design. Variables of the treatment such as cell source, treatment time, cell number and injection method need to be notarized. The safety of such therapy also needs to be carefully assessed.

The preservation and clinical use of stem cells are both challenging. Current clinical trials have mainly used freshly thawed cell stocks [42]. However, cryopreservation and thawing may affect the viability and functionalities of the stem cells [121, 122]. Cryopreservation can cause reversible and irreversible cryoinjuries to the stem cells, leading to host T-cell cytolysis, and affect the survival, distribution and immunosuppressive properties of exogenous stem cells [121, 123]. MSCs are not intrinsically immune-privileged and their transplants may induce immune rejection. Allogeneic MSCs may induce a memory T-cell response under certain conditions, resulting in rejection of allogeneic stem cells $[124,125]$. Furthermore, extensive in vitro expansion of stem cells may trigger replicative senescence, thereby affecting their therapeutic effectiveness [126].

With regard to the mechanism of stem cell therapy, previous studies showed that it relied on the appropriate homing and engraftment capacity of stem cells [127]. To date, increasing evidence suggested that the key mechanism of stem cell therapy is related to their paracrine pathway rather than ability for differentiation. Stem cell-mediated paracrine factors may therefore overcome the limitations of cell-based therapy, though its effectiveness and safety need to be further validated. It has also been discovered recently that stem cells will die rapidly and be cleared by innate immune cells after transplantation, which suggested that reprogramming of the immune cells may enhance the therapeutic effect (Fig. 3) [128].

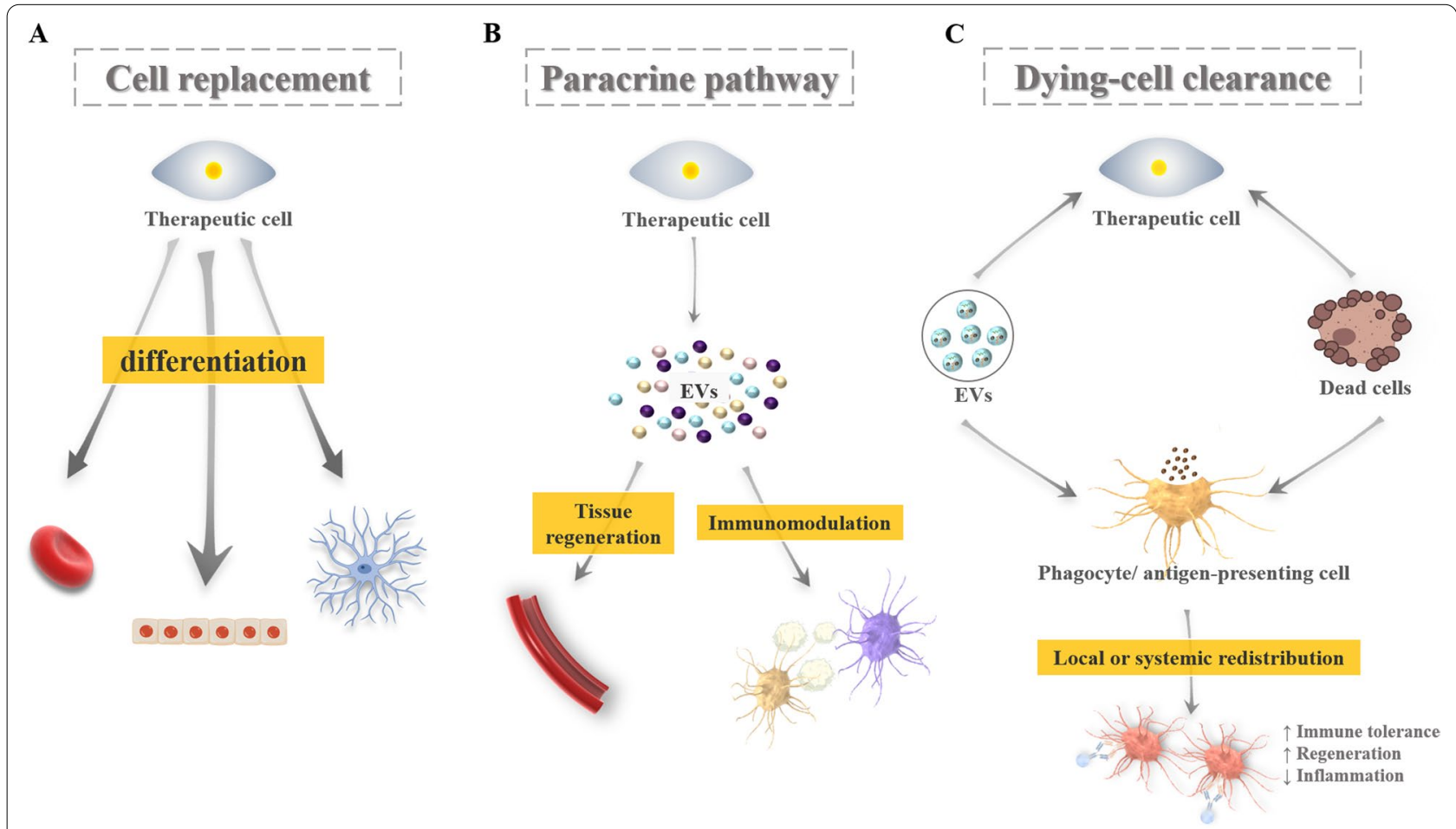

Fig. 3 Potential mechanisms of stem cell-based therapy. A Cell replacement by stem cells multi-lineage differentiation. B Cell communication though paracrine signaling; C: Dying cell clearance through phagocytosis. Adapted from Wagoner and Zhao [128] 


\section{Conclusion and future perspective}

As a pervasively common postoperative complication of intrauterine surgery, IUA will inevitably affect the reproductive capability and full recovery of the endometrium, which constitute a vital role in reproduction and maternal health. Over the past a few decades, hysteroscopy, hormone therapy, and application of intrauterine devices have been tried to tackle IUA, but all showed some shortcomings. In recent years, exploitation of stem cell therapy to restore injured endometrium has become a promising new treatment approach. A growing number of animal experiments and clinical trials have focused on the effect and mechanisms with respect to stem cell therapy. Studies have shown that application of stem cells derived from bone marrow, endometrium, menstrual blood, adipose, embryo, and cord blood can facilitate restoration of the structure and function of the uterus. In addition, combination of stem cells with biopolymer materials such as scaffolds, hydrogel, and nanostructure lipid carrier, can improve its delivery and enhance the survival and therapeutic effect of transplanted cells. Stem cellbased therapy can promote the regeneration and repair of endometrium, disrupt formation of fibrosis, and promote regeneration of blood vessels through paracrine and immune modulations.

Nevertheless, there are also risks for stem cell-based therapy. The mechanism by which stem cells can promote endometrial regeneration is still unclear. In addition, immunogenicity and tumorigenicity should not be ignored, as previous context has stated that teratoma is a main obstacle to the clinical usage of stem cell-based therapies, in particular embryonic stem cells. Therefore, the selection of stable and safe stem cell types and transplantation methods requires more research.

In summary, the ability of stem cells to self-differentiate and distinct regeneration mechanism have made them an attractive candidate for treating gynecological diseases such as the IUA.

\footnotetext{
Abbreviations

ADSCs: Adipose-derived stem cells; ADSC-exo: Exosomes from ADSCs; AECs: Amniotic epithelial cells; AHAM: Acellular human amniotic membrane; AMSCs: Amniotic mesenchymal stromal cells; AS: Asherman's syndrome; ASCs: Amniotic membrane stem cells; BM-MSCs: Bone marrow mesenchymal stem cells; BMSCs: Bone marrow stem cells; CS: Collagen scaffold; EnSCs: Endometrial stem/progenitor cells; EnSCs-CM: EnSCs conditioned medium; EMA: The European Medicine Agency; eMSCs: Endometrial mesenchymal stem cells; EpCAM: Epithelial cell adhesion molecule; EPCs: Endothelial progenitor cells; ESCs: Embryonic stem cells; ESP: Endometrial side population; EVs: Extracellular vesicles; G-CSF: Granulocyte-colony stimulating factor; GFP: Green fluorescent protein; HA: Hyaluronic acid; hEnSCs: Human endometrial mesenchymal stem cells; HSG: Hysterosalpingography; hUCMSCs-EV: EV derived from hUC-MSCs; HUVECs: Human umbilical vein endothelial cells; IUA: Intrauterine adhesion; IUD: Intrauterine device; LIF: Leukemic inhibition factor; MSCs: Mesenchymal stem/stromal cells; PGS: Poly (glycerol sebacate); PRP: Platelet-rich plasma; SP: Side population; TCRA: Transcervical resection of the adhesions; UC-MSCs: Umbilical cord-derived mesenchymal stromal cells.
}

Acknowledgements

Not applicable.

\section{Authors' contributions}

YTS and PCL drafted the manuscript; JT, CYZ and QJL contributed to the analysis of the results, JLL and HQX reviewed and modified the manuscript. All authors agreed on the final version. All authors read and approved the final manuscript.

\section{Funding}

This work was supported by the National Natural Science Foundation of China (Grant No. 31771065) and the 1.3.5 Project for Disciplines of Excellence, West China Hospital, Sichuan University (Grant No. ZYJC18002).

Availability of data and materials

Not applicable.

\section{Declarations}

Ethics approval and consent to participate

Not applicable.

\section{Consent for publication}

Not applicable.

\section{Competing interests}

The authors declare that they have no competing interests.

\section{Author details}

${ }^{1}$ Laboratory of Stem Cell and Tissue Engineering, Orthopedic Research Institute, Med-X Center for Materials, State Key Laboratory of Biotherapy, West China Hospital, Sichuan University, Chengdu 610041, China. ${ }^{2}$ Department of Medical Genetics, West China Second Hospital, Sichuan University, Chengdu 610041, China.

Received: 30 June 2021 Accepted: 4 October 2021

Published online: 30 October 2021

\section{References}

1. Asherman JG. Amenorrhoea Traumatica (Atretica). J Obstet Gynaecol Br Emp. 1948;55(1):23-30. https://doi.org/10.1111/j.1471-0528.1948.tb070 $45 x$

2. March CM. Management of Asherman's syndrome. Reprod Biomed Online. 2011;23(1):63-76. https://doi.org/10.1016/j.rbmo.2010.11.018.

3. Zhu H, Pan Y, Jiang Y, Li J, Zhang Y, Zhang S. Activation of the Hippo/TAZ pathway is required for menstrual stem cells to suppress myofibroblast and inhibit transforming growth factor beta signaling in human endometrial stromal cells. Hum Reprod. 2019;34(4):635-45. https://doi.org/ 10.1093/humrep/dez001.

4. Dreisler E, Kjer JJ. Asherman's syndrome: current perspectives on diagnosis and management. Int J Womens Health. 2019;2019(11):191-8. https://doi.org/10.2147/IJWH.S165474.eCollection.

5. Santamaria X, Isaacson K, Simon C. Asherman's syndrome: it may not be all our fault. Hum Reprod. 2018;33(8):1374-80. https://doi.org/10.1093/ humrep/dey232.

6. Deans R, Abbott J. Review of intrauterine adhesions. J Minim Invasive Gynecol. 2010;17(5):555-69. https://doi.org/10.1016/j.jmig.2010.04.016.

7. Schenker JG, Margalioth EJ. Intrauterine adhesions: an updated appraisal. Fertil Steril. 1982;37(5):593-610. https://doi.org/10.1016/ s0015-0282(16)46268-0.

8. Evans-Hoeker EA, Young SL. Endometrial receptivity and intrauterine adhesive disease. Semin Reprod Med. 2014;32(5):392-401. https://doi. org/10.1055/s-0034-1376358.

9. Yu D, Wong YM, Cheong Y, Xia E, Li TC. Asherman syndrome-one century later. Fertil Steril. 2008;89(4):759-79. https://doi.org/10.1016/j.fertn stert.2008.02.096.

10. Sahin Ersoy G, Zolbin MM, Cosar E, Moridi I, Mamillapalli R, Taylor HS CXCL12 promotes stem cell recruitment and uterine repair after injury 
in Asherman's syndrome. Mol Ther Methods Clin Dev. 2017;4:169-77. https://doi.org/10.1016/j.omtm.2017.01.001.

11. March CM, Israel R, March AD. Hysteroscopic management of intrauterine adhesions. Am J Obstet Gynecol. 1978;130(6):653-7. https://doi.org/ 10.1016/0002-9378(78)90322-8.

12. Ventolini $G$, Zhang $M$, Gruber J. Hysteroscopy in the evaluation of patients with recurrent pregnancy loss: a cohort study in a primary care population. Surg Endosc. 2004;18(12):1782-4. https://doi.org/10.1007/ s00464-003-8258-y.

13. Guimarães Filho HA, Mattar R, Pires CR, Araujo Júnior E, Moron AF, Nardozza LM. Comparison of hysterosalpingography, hysterosonography and hysteroscopy in evaluation of the uterine cavity in patients with recurrent pregnancy losses. Arch Gynecol Obstet. 2006;274(5):284-8. https://doi.org/10.1007/s00404-006-0186-3.

14. Hooker AB, Lemmers M, Thurkow AL, Heymans MW, Opmeer BC, Brölmann HA, et al. Systematic review and meta-analysis of intrauterine adhesions after miscarriage: prevalence, risk factors and long-term reproductive outcome. Hum Reprod Update. 2014;20(2):262-78. https://doi.org/10.1093/humupd/dmt045.

15. Pabuçcu R, Atay V, Orhon E, Urman B, Ergün A. Hysteroscopic treatment of intrauterine adhesions is safe and effective in the restoration of normal menstruation and fertility. Fertil Steril. 1997;68(6):1141-3. https:// doi.org/10.1016/s0015-0282(97)00375-0.

16. Foix A, Bruno RO, Davison T, Lema B. The pathology of postcurettage intrauterine adhesions. Am J Obstet Gynecol. 1966;96(7):1027-33. https://doi.org/10.1016/0002-9378(66)90452-2.

17. Conforti A, Alviggi C, Mollo A, De Placido G, Magos A. The management of Asherman syndrome: a review of literature. Reprod Biol Endocrinol. 2013;11:118. https://doi.org/10.1186/1477-7827-11-118.

18. Demir R, Yaba A, Huppertz B. Vasculogenesis and angiogenesis in the endometrium during menstrual cycle and implantation. Acta Histochem. 2010;112(3):203-14. https://doi.org/10.1016/j.acthis.2009.04.004.

19. Zhou Q, Wu X, Hu J, Yuan R. Abnormal expression of fibrosis markers, estrogen receptor a and stromal derived factor- $1 /$ chemokine (C-X-C motif) receptor-4 axis in intrauterine adhesions. Int J Mol Med. 2018:42(1):81-90. https://doi.org/10.3892/ijmm.2018.3586.

20. Guo LP, Chen LM, Chen F, Jiang NH, Sui L. Smad signaling coincides with epithelial-mesenchymal transition in a rat model of intrauterine adhesion. Am J TransI Res. 2019;11(8):4726-37.

21. Ning J, Zhang $\mathrm{H}$, Yang $\mathrm{H}$. MicroRNA-326 inhibits endometrial fibrosis by regulating TGF- $\beta 1 / \mathrm{Smad} 3$ pathway in intrauterine adhesions. Mol Med Rep. 2018;18(2):2286-92. https://doi.org/10.3892/mmr.2018.9187.

22. Chen X, Sun J, Li X, Mao L, Zhou Y, Cui L, et al. Antifibrotic effects of decellularized and lyophilized human amniotic membrane transplant on the formation of intrauterine adhesion. Exp Clin Transplant. 2019;17(2):236-42. https://doi.org/10.6002/ect.2017.0284.

23. Hu J, Zeng B, Jiang $X$, Hu L, Meng Y, Zhu Y, et al. The expression of marker for endometrial stem cell and fibrosis was increased in intrauterine adhesious. Int J Clin Exp Pathol. 2015;8(2):1525-34.

24. Shaffer $W$. Role of uterine adhesions in the cause of multiple pregnancy losses. Clin Obstet Gynecol. 1986;29(4):912-24. https://doi.org/10.1097/ 00003081-198612000-00016.

25. Toaff R, Ballas S. Traumatic hypomenorrhea-amenorrhea (Asherman's syndrome). Fertil Steril. 1978;30(4):379-87. https://doi.org/10.1016/ s0015-0282(16)43568-5.

26. The American Fertility Society. The American Fertility Society classifications of adnexal adhesions distal tubal occlusion, tubal occlusion secondary to tubal ligation, tubal pregnancies, Müllerian anomalies and intrauterine adhesions. Fertil Steril. 1988;49(6):944-55. https://doi.org/ 10.1016/s0015-0282(16)59942-7.

27. Valle RF, Sciarra JJ. Intrauterine adhesions: hysteroscopic diagnosis, classification, treatment, and reproductive outcome. Am J Obstet Gynecol. 1988;158(6 Pt 1):1459-70. https://doi.org/10.1016/0002-9378(88) 90382-1.

28. Nasr AL, Al-Inany HG, Thabet SM, Aboulghar M. A clinicohysteroscopic scoring system of intrauterine adhesions. Gynecol Obstet Invest. 2000;50(3):178-81. https://doi.org/10.1159/000010305.

29. AAGL Elevating Gynecologic Surgery. AAGL practice report: practice guidelines on intrauterine adhesions developed in collaboration with the European Society of Gynaecological Endoscopy (ESGE). Gynecol Surg. 2017;14(1):6. https://doi.org/10.1186/s10397-017-1007-3.
30. Sugimoto O. Diagnostic and therapeutic hysteroscopy for traumatic intrauterine adhesions. Am J Obstet Gynecol. 1978;131(5):539-47. https://doi.org/10.1016/0002-9378(78)90116-3.

31. Rein DT, Schmidt T, Hess AP, Volkmer A, Schöndorf T, Breidenbach M. Hysteroscopic management of residual trophoblastic tissue is superior to ultrasound-guided curettage. J Minim Invasive Gynecol. 2011;18(6):774-8. https://doi.org/10.1016/j.jmig.2011.08.003.

32. Liu F, Hu S, Wang S, Cheng K. Cell and biomaterial-based approaches to uterus regeneration. Regen Biomater. 2019;6(3):141-8. https://doi.org/ 10.1093/rb/rbz021.

33. Acunzo G, Guida M, Pellicano M, Tommaselli GA, Di Spiezio SA, Bifulco $G$, et al. Effectiveness of auto-cross-linked hyaluronic acid gel in the prevention of intrauterine adhesions after hysteroscopic adhesiolysis: a prospective, randomized, controlled study. Hum Reprod. 2003;18(9):1918-21. https://doi.org/10.1093/humrep/deg368.

34. Zhang SS, Xia WT, Xu J, Xu HL, Lu CT, Zhao YZ, et al. Three-dimensional structure micelles of heparin-poloxamer improve the therapeutic effect of $17 \beta$-estradiol on endometrial regeneration for intrauterine adhesions in a rat model. Int J Nanomed. 2017;12:5643-57. https://doi.org/10. 2147/IJN.S137237.

35. Aghajanova L, Cedars MI, Huddleston HG. Platelet-rich plasma in the management of Asherman syndrome: case report. J Assist Reprod Genet. 2018;35(5):771-5. https://doi.org/10.1007/s10815-018-1135-3.

36. Gan L, Duan H, Sun FQ, Xu Q, Tang YQ, Wang S. Efficacy of freeze-dried amnion graft following hysteroscopic adhesiolysis of severe intrauterine adhesions. Int J Gynaecol Obstet. 2017;137(2):116-22. https://doi. org/10.1002/ijgo.12112.

37. Chan RW, Schwab KE, Gargett CE. Clonogenicity of human endometrial epithelial and stromal cells. Biol Reprod. 2004;70(6):1738-50. https://doi org/10.1095/biolreprod.103.024109.

38. Prianishnikov VA. On the concept of stem cell and a model of functional-morphological structure of the endometrium. Contraception. 1978;18(3):213-23. https://doi.org/10.1016/s0010-7824(78)80015-8.

39. Gargett CE, Schwab KE, Deane JA. Endometrial stem/progenitor cells: the first 10 years. Hum Reprod Update. 2016;22(2):137-63. https://doi. org/10.1093/humupd/dmv051.

40. Schwab KE, Chan RW, Gargett CE. Putative stem cell activity of human endometrial epithelial and stromal cells during the menstrual cycle. Fertil Steril. 2005;84(Suppl 2):1124-30. https://doi.org/10.1016/j.fertn stert.2005.02.056.

41. Nitzsche F, Müller C, Lukomska B, Jolkkonen J, Deten A, Boltze J. Concise review: MSC adhesion cascade-insights into homing and transendothelial migration. Stem Cells. 2017;35(6):1446-60. https://doi.org/10. 1002/stem.2614.

42. Ullah M, Liu DD, Thakor AS. Mesenchymal stromal cell homing: mechanisms and strategies for improvement. iscience. 2019;15:421-38. https://doi.org/10.1016/j.isci.2019.05.004.

43. Xiang E, Han B, Zhang Q, Rao W, Wang Z, Chang C, et al. Human umbilical cord-derived mesenchymal stem cells prevent the progression of early diabetic nephropathy through inhibiting inflammation and fibrosis. Stem Cell Res Ther. 2020;11(1):336. https://doi.org/10.1186/ s13287-020-01852-y.

44. Min J, Lu N, Huang S, Chai X, Wang S, Peng L, Wang J. Phenotype and biological characteristics of endometrial mesenchymal stem/stromal cells: a comparison between intrauterine adhesion patients and healthy women. Am J Reprod Immunol. 2021;85(6): e13379. https://doi. org/10.1111/aji.13379.

45. Gargett CE, Ye L. Endometrial reconstruction from stem cells. Fertil Steril. 2012;98(1):11-20. https://doi.org/10.1016/j.fertnstert.2012.05.004.

46. Liu Y, Tal R, Pluchino N, Mamillapalli R, Taylor HS. Systemic administration of bone marrow-derived cells leads to better uterine engraftment than use of uterine-derived cells or local injection. J Cell Mol Med. 2018;22(1):67-76. https://doi.org/10.1111/jcmm.13294.

47. Abomaray FM, Al Jumah MA, Alsaad KO, Jawdat D, Al Khaldi A, AlAskar AS, et al. Phenotypic and functional characterization of mesenchymal stem/multipotent stromal cells from decidua basalis of human term placenta. Stem Cells Int. 2016;2016:5184601. https://doi.org/10.1155/ 2016/5184601.

48. Nagori CB, Panchal SY, Patel H. Endometrial regeneration using autologous adult stem cells followed by conception by in vitro fertilization 
in a patient of severe Asherman's syndrome. J Hum Reprod Sci. 2011;4(1):43-8. https://doi.org/10.4103/0974-1208.82360.

49. Masuda H, Maruyama T, Gargett CE, Miyazaki K, Matsuzaki Y, Okano H, et al. Endometrial side population cells: potential adult stem/progenitor cells in endometrium. Biol Reprod. 2015;93(4):84. https://doi.org/10. 1095/biolreprod.115.131490.

50. Gargett CE, Masuda H. Adult stem cells in the endometrium. Mol Hum Reprod. 2010;16(11):818-34. https://doi.org/10.1093/molehr/gaq061.

51. Masuda H, Anwar SS, Bühring HJ, Rao JR, Gargett CE. A novel marker of human endometrial mesenchymal stem-like cells. Cell Transplant. 2012;21(10):2201-14. https://doi.org/10.3727/096368911X637362.

52. Cervelló I, Mas A, Gil-Sanchis C, Peris L, Faus A, Saunders PT, et al. Reconstruction of endometrium from human endometrial side population cell lines. PLoS ONE. 2011;6(6):e21221. https://doi.org/10.1371/journal. pone.0021221.

53. Kato K, Yoshimoto M, Kato K, Adachi S, Yamayoshi A, Arima T, et al. Characterization of side-population cells in human normal endometrium. Hum Reprod. 2007;22(5):1214-23. https://doi.org/10.1093/humrep/ del514.

54. Xin L, Lin X, Pan Y, Zheng X, Shi L, Zhang Y, et al. A collagen scaffold loaded with human umbilical cord-derived mesenchymal stem cells facilitates endometrial regeneration and restores fertility. Acta Biomater. 2019;92:160-71. https://doi.org/10.1016/j.actbio.2019.05.012.

55. Ding DC, Chang YH, Shyu WC, Lin SZ. Human umbilical cord mesenchymal stem cells: a new era for stem cell therapy. Cell Transplant. 2015;24(3):339-47. https://doi.org/10.3727/096368915X686841.

56. Pittenger MF, Mackay AM, Beck SC, Jaiswal RK, Douglas R, Mosca JD, et al. Multilineage potential of adult human mesenchymal stem cells. Science. 1999;284(5411):143-7. https://doi.org/10.1126/science.284. 5411.143.

57. Tsekouras A, Mantas D, Tsilimigras DI, Moris D, Kontos M, Zografos GC Comparison of the viability and yield of adipose-derived stem cells (ASCs) from different donor areas. In Vivo. 2017;31(6):1229-34. https:// doi.org/10.21873/invivo.11196.

58. Duscher D, Maan ZN, Luan A, Aitzetmüller MM, Brett EA, Atashroo D, et al. Ultrasound-assisted liposuction provides a source for functional adipose-derived stromal cells. Cytotherapy. 2017;19(12):1491-500. https://doi.org/10.1016/j.jcyt.2017.07.013.

59. Bacakova L, Zarubova J, Travnickova M, Musilkova J, Pajorova J, Slepicka $P$, et al. Stem cells: their source, potency and use in regenerative therapies with focus on adipose-derived stem cells-a review. Biotechnol Adv. 2018;36(4):1111-26. https://doi.org/10.1016/j.biotechadv.2018.03. 011.

60. Xie Q, Wei W, Ruan J, Ding Y, Zhuang A, Bi X, et al. Effects of miR-146a on the osteogenesis of adipose-derived mesenchymal stem cells and bone regeneration. Sci Rep. 2017;7:42840. https://doi.org/10.1038/ srep42840.

61. Cheung HK, Han TT, Marecak DM, Watkins JF, Amsden BG, Flynn LE. Composite hydrogel scaffolds incorporating decellularized adipose tissue for soft tissue engineering with adipose-derived stem cells. Biomaterials. 2014;35(6):1914-23. https://doi.org/10.1016/j.biomaterials. 2013.11.067.

62. Thomson JA, Itskovitz-Eldor J, Shapiro SS, Waknitz MA, Swiergiel JJ, Marshall VS, Jones JM. Embryonic stem cell lines derived from human blastocysts. Science. 1998;282(5391):1145-7. https://doi.org/10.1126/ science.282.5391.1145.Erratum.In:Science1998;282(5395):1827.

63. Mountford JC. Human embryonic stem cells: origins, characteristics and potential for regenerative therapy. Transfus Med. 2008;18(1):1-12. https://doi.org/10.1111/j.1365-3148.2007.00807.x.

64. Lindenmair A, Hatlapatka T, Kollwig G, Hennerbichler S, Gabriel C, Wolbank S, et al. Mesenchymal stem or stromal cells from amnion and umbilical cord tissue and their potential for clinical applications. Cells. 2012;1 (4):1061-88. https://doi.org/10.3390/cells 1041061.

65. Parolini O, Caruso M. Review: preclinical studies on placenta-derived cells and amniotic membrane: an update. Placenta. 2011;32(Suppl 2):S186-95. https://doi.org/10.1016/.placenta.2010.12.016.

66. Jiao H, Shi K, Zhang W, Yang L, Yang L, Guan F, et al. Therapeutic potential of human amniotic membrane-derived mesenchymal stem cells in APP transgenic mice. Oncol Lett. 2016;12(3):1877-83. https://doi.org/ 10.3892/ol.2016.4857.
67. Niknejad H, Paeini-Vayghan G, Tehrani FA, Khayat-Khoei M, Peirovi H Side dependent effects of the human amnion on angiogenesis. Placenta. 2013;34(4):340-5. https://doi.org/10.1016/.placenta.2013.02.001.

68. Yan K, Zhang R, Chen L, Chen F, Liu Y, Peng L, et al. Nitric oxide-mediated immunosuppressive effect of human amniotic membrane-derived mesenchymal stem cells on the viability and migration of microglia. Brain Res. 2014:1590:1-9. https://doi.org/10.1016/j.brainres.2014.05.041.

69. Yazdanpanah G, Paeini-Vayghan G, Asadi S, Niknejad H. The effects of cryopreservation on angiogenesis modulation activity of human amniotic membrane. Cryobiology. 2015;71(3):413-8. https://doi.org/10. 1016/j.cryobiol.2015.09.008.

70. Mints M, Jansson M, Sadeghi B, Westgren M, Uzunel M, Hassan M, Palmblad J. Endometrial endothelial cells are derived from donor stem cells in a bone marrow transplant recipient. Hum Reprod. 2008;23(1):139-43. https://doi.org/10.1093/humrep/dem342.

71. Cervelló I, Gil-Sanchis C, Mas A, Faus A, Sanz J, Moscardó F, et al. Bone marrow-derived cells from male donors do not contribute to the endometrial side population of the recipient. PLoS ONE. 2012;7(1):e30260. https://doi.org/10.1371/journal.pone.0030260.

72. Cervelló I, Gil-Sanchis C, Santamaría X, Cabanillas S, Díaz A, Faus A, et al. Human CD133(+) bone marrow-derived stem cells promote endometrial proliferation in a murine model of Asherman syndrome. Fertil Steril. 2015;104(6):1552-60e1-3. https://doi.org/10.1016/j.fertnstert.2015.08. 032.

73. Gao L, Huang Z, Lin H, Tian Y, Li P, Lin S. Bone marrow mesenchymal stem cells (BMSCs) restore functional endometrium in the rat model for severe Asherman syndrome. Reprod Sci. 2019;26(3):436-44. https://doi. org/10.1177/1933719118799201.

74. Wang J, Ju B, Pan C, Gu Y, Zhang Y, Sun L, et al. Application of bone marrow-derived mesenchymal stem cells in the treatment of intrauterine adhesions in rats. Cell Physiol Biochem. 2016;39(4):1553-60. https:// doi.org/10.1159/000447857.

75. Santamaria X, Cabanillas S, Cervelló I, Arbona C, Raga F, Ferro J, et al. Autologous cell therapy with $\mathrm{CD}_{133^{+}}$bone marrow-derived stem cells for refractory Asherman's syndrome and endometrial atrophy: a pilot cohort study. Hum Reprod. 2016;31(5):1087-96. https://doi.org/10. 1093/humrep/dew042.

76. Zhao G, Cao Y, Zhu X, Tang X, Ding L, Sun H, et al. Transplantation of collagen scaffold with autologous bone marrow mononuclear cells promotes functional endometrium reconstruction via downregulating $\triangle$ Np63 expression in Asherman's syndrome. Sci China Life Sci. 2017:60(4):404-16. https://doi.org/10.1007/s11427-016-0328-y.

77. Ding L, Li X, Sun H, Su J, Lin N, Péault B, et al. Transplantation of bone marrow mesenchymal stem cells on collagen scaffolds for the functional regeneration of injured rat uterus. Biomaterials. 2014;35(18):4888-900. https://doi.org/10.1016/j.biomaterials.2014.02. 046.

78. Xiao B, Zhu Y, Huang J, Wang T, Wang F, Sun S. Exosomal transfer of bone marrow mesenchymal stem cell-derived miR-340 attenuates endometrial fibrosis. Biol Open. 2019;8(5):bio39958. https://doi.org/10. 1242/bio.039958.

79. Xiao B, Yang W, Lei D, Huang J, Yin Y, Zhu Y, et al. PGS Scaffolds promote thein vivo survival and directional differentiation of bone marrow mesenchymal stem cells restoring the morphology and function of wounded rat uterus. Adv Healthc Mater. 2019;8(5):e1801455. https:// doi.org/10.1002/adhm.201801455.

80. Marinaro F, Gómez-Serrano M, Jorge I, Silla-Castro JC, Vázquez J, Sánchez-Margallo FM, et al. Unraveling the molecular signature of extracellular vesicles from endometrial-derived mesenchymal stem cells: potential modulatory effects and therapeutic applications. Front Bioeng Biotechnol. 2019;7:431. https://doi.org/10.3389/fbioe.2019. 00431.

81. Bhurke A, Kannan A, Neff A, Ma Q, Laws MJ, Taylor RN, et al. A hypoxia-induced Rab pathway regulates embryo implantation by controlled trafficking of secretory granules. Proc Natl Acad Sci USA. 2020;117(25):14532-42. https://doi.org/10.1073/pnas.2000810117.

82. Zhu X, Yu F, Yan G, Hu Y, Sun H, Ding L. Human endometrial perivascular stem cells exhibit a limited potential to regenerate endometrium after xenotransplantation. Hum Reprod. 2021;36(1):145-59. https://doi.org/ 10.1093/humrep/deaa261. 
83. Ulrich D, Tan KS, Deane J, Schwab K, Cheong A, Rosamilia A, et al. Mesenchymal stem/stromal cells in post-menopausal endometrium. Hum Reprod. 2014;29(9):1895-905. https://doi.org/10.1093/humrep/deu159.

84. Li Z, Yan G, Diao Q, Yu F, Li X, Sheng X, et al. Transplantation of human endometrial perivascular cells with elevated CYR61 expression induces angiogenesis and promotes repair of a full-thickness uterine injury in rat. Stem Cell Res Ther. 2019;10(1):179. https://doi.org/10.1186/ s13287-019-1272-3.

85. Gurung S, Deane JA, Masuda H, Maruyama T, Gargett CE. Stem cells in endometrial physiology. Semin Reprod Med. 2015;33(5):326-32. https:// doi.org/10.1055/s-0035-1558405.

86. Gargett CE. Uterine stem cells: what is the evidence? Hum Reprod Update. 2007;13(1):87-101. https://doi.org/10.1093/humupd/dml045.

87. Zhang Y, Lin X, Dai Y, Hu X, Zhu H, Jiang Y, et al. Endometrial stem cells repair injured endometrium and induce angiogenesis via AKT and ERK pathways. Reproduction. 2016;152(5):389-402. https://doi.org/10.1530/ REP-16-0286.

88. Zhang S, Li P, Yuan Z, Tan J. Platelet-rich plasma improves therapeutic effects of menstrual blood-derived stromal cells in rat model of intrauterine adhesion. Stem Cell R Ther. 2019;10(1):61. https://doi.org/ 10.1186/s13287-019-1155-7

89. Lin X, Zhang Y, Pan Y, He S, Dai Y, Zhu B, Wei C, Xin L, Xu W, Xiang C, Zhang $S$. Endometrial stem cell-derived granulocyte-colony stimulating factor attenuates endometrial fibrosis via sonic hedgehog transcriptional activator Gli2. Biol Reprod. 2018;98(4):480-90.

90. Tan J, Li P, Wang Q, Li Y, Li X, Zhao D, et al. Autologous menstrual bloodderived stromal cells transplantation for severe Asherman's syndrome. Hum Reprod. 2016;31(12):2723-9. https://doi.org/10.1093/humrep/ dew235.

91. Álvarez V, Sánchez-Margallo FM, Macías-García B, Gómez-Serrano M, Jorge I, Vázquez J, et al. The immunomodulatory activity of extracelIular vesicles derived from endometrial mesenchymal stem cells on $\mathrm{CD}^{+} \mathrm{T}$ cells is partially mediated by TGFbeta. J Tissue Eng Regen Med. 2018;12(10):2088-98. https://doi.org/10.1002/term.2743.

92. Zhang L, Li Y, Guan CY, Tian S, Lv XD, Li JH, et al. Therapeutic effect of human umbilical cord-derived mesenchymal stem cells on injured rat endometrium during its chronic phase. Stem Cell Res Ther. 2018;9(1):36. https://doi.org/10.1186/s13287-018-0777-5.

93. Zheng JH, Zhang JK, Kong DS, Song YB, Zhao SD, Qi WB, et al. Quantification of the CM-Dil-labeled human umbilical cord mesenchymal stem cells migrated to the dual injured uterus in SD rat. Stem Cell Res Ther. 2020;11(1):280. https://doi.org/10.1186/s13287-020-01806-4.

94. Liu J, Zhang H, Zhang Y, Li N, Wen Y, Cao F, et al. Homing and restorative effects of bone marrow-derived mesenchymal stem cells on cisplatin injured ovaries in rats. Mol Cells. 2014;37(12):865-72. https://doi.org/10. 14348/molcells.2014.0145.

95. Chen Y, Qian H, Zhu W, Zhang X, Yan Y, Ye S, et al. Hepatocyte growth factor modification promotes the amelioration effects of human umbilical cord mesenchymal stem cells on rat acute kidney injury. Stem Cells Dev. 2011;20(1):103-13. https://doi.org/10.1089/scd.2009.0495.

96. Ebrahim N, Mostafa O, El Dosoky RE, Ahmed IA, Saad AS, Mostafa A, et al. Human mesenchymal stem cell-derived extracellular vesicles/ estrogen combined therapy safely ameliorates experimentally induced intrauterine adhesions in a female rat model. Stem Cell Res Ther 2018;9(1):175. https://doi.org/10.1186/s13287-018-0924-z.

97. Xu L, Ding L, Wang L, Cao Y, Zhu H, Lu J, et al. Umbilical cord-derived mesenchymal stem cells on scaffolds facilitate collagen degradation via upregulation of MMP-9 in rat uterine scars. Stem Cell Res Ther. 2017;8(1):84. https://doi.org/10.1186/s13287-017-0535-0.

98. Wang L, Yu C, Chang T, Zhang M, Song S, Xiong C, et al. In situ repair abilities of human umbilical cord-derived mesenchymal stem cells and autocrosslinked hyaluronic acid gel complex in rhesus monkeys with intrauterine adhesion. Sci Adv. 2020;6(21):eaba6357. https://doi.org/10. 1126/sciadv.aba6357.

99. Cao Y, Sun H, Zhu H, Zhu X, Tang X, Yan G, et al. Allogeneic cell therapy using umbilical cord MSCs on collagen scaffolds for patients with recurrent uterine adhesion: a phase I clinical trial. Stem Cell Res Ther. 2018;9(1):192. https://doi.org/10.1186/s13287-018-0904-3.

100. Shao X, Ai G, Wang L, Qin J, Li Y, Jiang H, et al. Adipose-derived stem cells transplantation improves endometrial injury repair. Zygote. 2019;27(6):367-74. https://doi.org/10.1017/S096719941900042X.
101. Sun H, Lu J, Li B, Chen S, Xiao X, Wang J, et al. Partial regeneration of uterine horns in rats through adipose-derived stem cell sheets. Biol Reprod. 2018;99(5):1057-69. https://doi.org/10.1093/biolre/ioy121.

102. Wei F, Qu C, Song T, Ding G, Fan Z, Liu D, et al. Vitamin C treatment promotes mesenchymal stem cell sheet formation and tissue regeneration by elevating telomerase activity. J Cell Physiol. 2012;227(9):3216-24. https://doi.org/10.1002/jcp.24012.

103. Han X, Ma Y, Lu X, LiW, Xia E, LiTC, et al. Transplantation of human adipose stem cells using acellular human amniotic membrane improves angiogenesis in injured endometrial tissue in a rat intrauterine adhesion model. Cell Transplant. 2020;29:963689720952055. https://doi.org/ $10.1177 / 0963689720952055$.

104. Zhao S, Qi W, Zheng J, Tian Y, Qi X, Kong D, et al. Exosomes derived from adipose mesenchymal stem cells restore functional endometrium in a rat model of intrauterine adhesions. Reprod Sci. 2020;27(6):1266-75. https://doi.org/10.1007/s43032-019-00112-6.

105. Zhao YX, Chen SR, Huang QY, Chen WC, Xia T, Shi YC, et al. Repair abilities of mouse autologous adipose-derived stem cells and ShakeGeI ${ }^{T M} 3 \mathrm{D}$ complex local injection with intrauterine adhesion by BMP7-Smad5 signaling pathway activation. Stem Cell Res Ther. 2021;12(1):191. https://doi.org/10.1186/s13287-021-02258-0.

106. Shroff G, Gupta R. Human embryonic stem cells in the treatment of patients with spinal cord injury. Ann Neurosci. 2015;22(4):208-16. https://doi.org/10.5214/ans.0972.7531.220404.

107. Shiba Y, Fernandes S, Zhu WZ, Filice D, Muskheli V, Kim J, et al. Human ES-cell-derived cardiomyocytes electrically couple and suppress arrhythmias in injured hearts. Nature. 2012;489(7415):322-5. https://doi. org/10.1038/nature11317.

108. Tolosa L, Caron J, Hannoun Z, Antoni M, López S, Burks D, et al. Transplantation of hESC-derived hepatocytes protects mice from liver injury. Stem Cell Res Ther. 2015;6:246. https://doi.org/10.1186/ s13287-015-0227-6.

109. Bruin JE, Saber N, Braun N, Fox JK, Mojibian M, Asadi A, et al. Treating diet-induced diabetes and obesity with human embryonic stem cellderived pancreatic progenitor cells and antidiabetic drugs. Stem Cell Rep. 2015;4(4):605-20. https://doi.org/10.1016/j.stemcr.2015.02.011.

110. Cheng A, Kapacee Z, Peng J, Lu S, Lucas RJ, Hardingham TE, et al. Cartilage repair using human embryonic stem cell-derived chondroprogenitors. Stem Cells Transl Med. 2014;3(11):1287-94. https://doi.org/ 10.5966/sctm.2014-0101.

111. Yu W, Niu W, Wang S, Chen X, Sun BO, Wang F, et al. Co-culture with endometrial stromal cells enhances the differentiation of human embryonic stem cells into endometrium-like cells. Exp Ther Med. 2015;10(1):43-50. https://doi.org/10.3892/etm.2015.2490.

112. Song $T$, Zhao X, Sun $H$, Li X, Lin N, Ding L, et al. Regeneration of uterine horns in rats using collagen scaffolds loaded with human embryonic stem cell-derived endometrium-like cells. Tissue Eng Part A. 2015;21(12):353-61. https://doi.org/10.1089/ten.TEA.2014.0052.

113. Gan L, Duan $H, X u$ Q, Tang YQ, Li JJ, Sun FQ, et al. Human amniotic mesenchymal stromal cell transplantation improves endometrial regeneration in rodent models of intrauterine adhesions. Cytotherapy. 2017;19(5):603-16. https://doi.org/10.1016/j.jcyt.2017.02.003.

114. Miki T. Stem cell characteristics and the therapeutic potential of amniotic epithelial cells. Am J Reprod Immunol. 2018;80(4):e13003. https:// doi.org/10.1111/aji.13003.

115. Cargnoni A, Piccinelli EC, Ressel L, Rossi D, Magatti M, Toschi I, et al. Conditioned medium from amniotic membrane-derived cells prevents lung fibrosis and preserves blood gas exchanges in bleomycin-injured mice-specificity of the effects and insights into possible mechanisms. Cytotherapy. 2014;16(1):17-32. https://doi.org/10.1016/j.jcyt.2013.07. 002.

116. Kakishita K, Elwan MA, Nakao N, Itakura T, Sakuragawa N. Human amniotic epithelial cells produce dopamine and survive after implantation into the striatum of a rat model of Parkinson's disease: a potential source of donor for transplantation therapy. Exp Neurol. 2000;165(1):27-34. https://doi.org/10.1006/exnr.2000.7449.

117. Ren $Y$, Chen $Y$, Zheng $X$, Wang H, Kang $X$, Tang J, et al. Human amniotic epithelial cells ameliorate kidney damage in ischemia-reperfusion mouse model of acute kidney injury. Stem Cell Res Ther. 2020;11(1):410. https://doi.org/10.1186/s13287-020-01917-y. 
118. Manuelpillai U, Tchongue J, Lourensz D, Vaghjiani V, Samuel CS, Liu A, et al. Transplantation of human amnion epithelial cells reduces hepatic fibrosis in immunocompetent $\mathrm{CCl}_{4}$-treated mice. Cell Transplant. 2010;19(9):1157-68. https://doi.org/10.3727/096368910X504496.

119. Li B, Zhang Q, Sun J, Lai D. Human amniotic epithelial cells improve fertility in an intrauterine adhesion mouse model. Stem Cell Res Ther. 2019;10(1):257. https://doi.org/10.1186/s13287-019-1368-9.

120. Lai D, Li B, Zhang Q, Wang Q. Use of amniotic epithelial cells for preparing medicine in preventing or repairing intrauterine adhesions and/ or endometrial damage by improving autophagy in injured endometrium. CN110251534-A.

121. Chinnadurai R, Copland IB, Garcia MA, Petersen CT, Lewis CN, Waller EK, et al. Cryopreserved mesenchymal stromal cells are susceptible to T-cell mediated apoptosis which is partly rescued by IFNy licensing. Stem Cells. 2016;34(9):2429-42. https://doi.org/10.1002/stem.2415.

122. Galipeau J. The mesenchymal stromal cells dilemma-does a negative phase III trial of random donor mesenchymal stromal cells in steroidresistant graft-versus-host disease represent a death knell or a bump in the road? Cytotherapy. 2013;15(1):2-8. https://doi.org/10.1016/j.jcyt. 2012.10 .002$.

123. François M, Copland IB, Yuan S, Romieu-Mourez R, Waller EK, Galipeau J. Cryopreserved mesenchymal stromal cells display impaired immunosuppressive properties as a result of heat-shock response and impaired interferon- $\gamma$ licensing. Cytotherapy. 2012;14(2):147-52. https://doi.org/ 10.3109/14653249.2011.623691.
124. Nauta AJ, Westerhuis G, Kruisselbrink AB, Lurvink EG, Willemze R, Fibbe WE. Donor-derived mesenchymal stem cells are immunogenic in an allogeneic host and stimulate donor graft rejection in a nonmyeloablative setting. Blood. 2006;108(6):2114-20. https://doi.org/10.1182/ blood-2005-11-011650.

125. Eliopoulos N, Stagg J, Lejeune L, Pommey S, Galipeau J. Allogeneic marrow stromal cells are immune rejected by $\mathrm{MHC}$ class $\mathrm{I}$ - and class II-mismatched recipient mice. Blood. 2005;106(13):4057-65. https://doi. org/10.1182/blood-2005-03-1004.

126. Capasso S, Alessio N, Squillaro T, Di Bernardo G, Melone MA, Cipollaro $M$, et al. Changes in autophagy, proteasome activity and metabolism to determine a specific signature for acute and chronic senescent mesenchymal stromal cells. Oncotarget. 2015;6(37):39457-68. https://doi.org/ 10.18632/oncotarget.6277.

127. Mozid AM, Arnous S, Sammut EC, Mathur A. Stem cell therapy for heart diseases. Br Med Bull. 2011;98:143-59. https://doi.org/10.1093/bmb/ Idr014.

128. Wagoner ZW, Zhao W. Therapeutic implications of transplanted-cell death. Nat Biomed Eng. 2021;5(5):379-84. https://doi.org/10.1038/ s41551-021-00729-6.

\section{Publisher's Note}

Springer Nature remains neutral with regard to jurisdictional claims in published maps and institutional affiliations.
Ready to submit your research? Choose BMC and benefit from:

- fast, convenient online submission

- thorough peer review by experienced researchers in your field

- rapid publication on acceptance

- support for research data, including large and complex data types

- gold Open Access which fosters wider collaboration and increased citations

- maximum visibility for your research: over $100 \mathrm{M}$ website views per year

At BMC, research is always in progress.

Learn more biomedcentral.com/submissions 